\title{
Nationalism, Biography and the Ecology of Identity
}

\author{
Jonathan Hearn
}

\section{Introduction}

Since confession has been one of the classic genres of biography since Saint Augustine wrote his, let me begin with a confession: I am not a biographer. But while I haven't worked on biography, my work on nationalism and national identity has frequently been carried out through ethnographic research, forcing me to grapple with the specificity and variability of national identity. However general the discursive categories of 'the nation' and 'nationalism', no two people do it exactly the same way. Over the years people have told me many different stories about the role of nationalism in their lives - stories that suggest that people attach themselves to, and detach themselves from, that category in ways that have irreducible personal narrative significance. So while I have not systematically investigated any individual life histories in regard to nationalism, my ethnographic research on nationalism has instilled in me a strong sense of being surrounded by individual biographies that, even if only partially glimpsed, each tell a specific story about how nationalism becomes significant for people.

One more disclaimer: there are of course extensive interdisciplinary literatures on narrative and biography as methods and modes of analysis. I am not attempting to engage those literatures. The key concept in my work has been 'identity', especially as applied to the study of nationalism, and that is how the present discussion is framed. An artisan normally works best with the tools with which they are most familiar, and that is what I have chosen to do here. But I also think there are specific advantages to this approach. We are interested here in relating biography to nationalism, individual lives to large, complex social structures. I hope to show that scrutinising the concept of identity helps us to foreground certain fundamental analytic problems involved in this venture.

I aim to provide a frame for the articles that follow in this issue. First, I explore the concept of 'identity' in the social sciences, both in general and in regard to nationalism. I emphasise an underlying ambivalence about relating persons to identities. Then I review and reconsider three metaphorical concepts that I have 
used to help make sense of identification processes: moods, ${ }^{1}$ embedding ${ }^{2}$ and ecology. ${ }^{3}$ As they arise sequentially in my work, I attempt here to synthesise them a bit, and offer them as a general perspective on the study of identity. The two most fundamental points that I want to stress are the need to clearly distinguish analytically between personal and social dimensions of identity, and that our existential need for power is fundamental to how we connect our personal identities, our biographies, to the social identity categories that surround us. In conclusion, I reflect on biography as a means of investigating these questions, and the centrality of power for the study of social life.

\section{Identities: National and otherwise}

'The national' is one dimension in which a general theory of identity, or identification, can be investigated and applied. Too often attempts to address national identity fail to provide or even contemplate a wider theory of identity that places the national in context, inviting comparisons with identity processes in other contexts. Particularly noticeable in the study of identity, especially in sociology and approaches informed by literary studies, is a deep unease with the idea of a stable, coherent, individual person. A kind of methodological dread of reifying and essentialising individual identities tends to skew much of the discussion. This poses certain problems in relating the study of identity to the doing of biography. Next I discuss some general approaches to the study of identity, and then more specifically approaches to national identity in particular. of course these discussions interpenetrate.

\section{Identity}

When social-science conceptions of identity first began to proliferate and flow into a wider popular discourse in the mid twentieth century, they were around notions of a tension between individual self-identity and a wider mass society. ${ }^{4}$ Concerns about the inhibiting and distorting effects of consumerism, conformism and bureaucracy on personal identity were part of what made concepts like Erik Erikson's 'identity crisis' particularly salient. ${ }^{5}$ A social psychologist and psychoanalyst, Erikson formulated his notion of identity crisis partly to understand the difficulties in making the transition from child to

1 Hearn, J. 2002, 'Narrative, agency, and mood: on the social construction of national history in Scotland', Comparative Studies in Society and History, vol. 44, no. 4, pp. 745-69.

2 Hearn, J. 2007, 'National identity: banal, personal, and embedded', Nations and Nationalism, vol. 13, no.

4, pp. 657-74.

3 Hearn, J. 2012, Theorizing Power, Palgrave Macmillan, Basingstoke, UK, pp. 200-7.

4 Wrong, D. H. 1968, 'Identity: problem and catchword', Dissent, vol. 15, pp. 427-35.

5 Erikson, E. 1968, Identity: Youth and crisis, Faber \& Faber, London. 
adult, through the rough passage of teenage-hood (an idea itself of fairly recent vintage). Employing cross-cultural research and comparison, he was interested in the different ways that societies equip their members with the emotional and symbolic resources to deal with the various stages of life. ${ }^{6}$ So when it first came to prominence, the academic-cum-popular discourse around identity tended to take for granted the reality and value of a constant if changing self-identity, locating social problems in the wider social environment that might threaten its relative stability.

Erikson has tended to be forgotten in recent decades. More enduring in contemporary discussions of identity has been the work of another social psychologist, Henri Tajfel. ${ }^{7} \mathrm{He}$ and his followers developed what is known as 'selfcategorisation theory' ${ }^{8}$ Tajfel, a Holocaust survivor, Polish Jew and prisoner of war, was deeply concerned about the nature of stereotyping and prejudice, for obvious reasons. His work focused primarily on 'social identities', understood as the process by which ideas of distinct social groups and membership in them are formed. Many of his basic formulations are now commonplace: 1) that we develop a sense of self through how we categorise ourselves; 2) that this involves notions of 'in-groups' to which we belong and 'out-groups' from which we are excluded; 3) that we tend to understand in and out-groups comparatively, valuing the former positively and the latter negatively; and 4) that these basic social processes create a powerful tendency to view the world in terms of 'we' versus 'they'. Without gainsaying the insights of Tajfel and his followers, we can note a conceptual subordination of personal to social identities here.

I move from social psychologists to sociologists and anthropologists who have worked on nationalism and national identity, but have helpfully posed their arguments in more general terms. Richard Jenkins places great emphasis on social identity categories as things that are not just 'claimed' or opted into, as often implied in studies of identity politics, but also imposed, as part of processes of domination and social control. ${ }^{9}$ Gravitating towards the symbolic interactionist tradition of Goffman, ${ }^{10}$ his approach to identity favours treating it as a pattern of observable social interaction. As he puts it: 'First, identity is a practical accomplishment, a process. Second, individual and collective identities can be understood using a unified model of the dialectical interplay of

\footnotetext{
6 Erikson, E. 1965, Childhood and Society, [Revised edn], Penguin, Harmondsworth, UK.

7 Tajfel, H. (ed.) 1978, Differentiation Between Social Groups: Studies in the social psychology of intergroup relations, Academic Press, London; Tajfel, H. (ed.) 1982, Social Identity and Intergroup Relations, Cambridge University Press, Cambridge.

8 Reicher, S. and Hopkins, N. 2001, Self and Nation, Sage, London.

9 Jenkins, R. 1994, 'Rethinking ethnicity: identity, categorization and power', Ethnic and Racial Studies, vol. 17, no. 2, pp. 197-223; Jenkins, R. 2000, 'Categorization: identity, social process and epistemology', Current Sociology, vol. 48, no. 3, pp. 7-25; Jenkins, R. 2004, Social Identity, [Second edn], Routledge, London, pp. 79-93.

10 Goffman, E. 1983, 'The interaction order', American Sociological Review, vol. 48, pp. 1-17.
} 
processes of internal and external definition.' ${ }^{11}$ So there is an acknowledgment of a distinction between 'internal' and 'external', but a reluctance to allow either one too much conceptual autonomy from the other. It is the interactive process that is most real.

Similarly, the anthropologist Thomas Hylland Eriksen suggests that '[w]hen we talk of identity in social anthropology, we refer to social identity, not to the depths of the individual mind'. ${ }^{12}$ The ethnographic approach of anthropology fosters an interest in how people actively invoke social identity categories, how they 'do' them, and what they mean to people as social actors. Thus, there is an interest in what real people are actually doing when they do identity. But again, as Eriksen's proviso indicates, this is an interest that brackets off the depths of the individual mind and that treats identity as action in terms of social categories, as something essentially public.

Rogers Brubaker sounds another, but different sceptical note about the concept of identity. ${ }^{13}$ In an influential theoretical essay written with Frederick Cooper, they argue that the prevailing constructivist approach to identity, of which Jenkins could be taken to be a representative, becomes so fluid that the idea of identity becomes meaningless. But far from a return to a 'hard' notion of fixed identity, they suggest that in fact 'identity' is of interest primarily as a 'category of practice' - that is, something the people we study often believe in, and which guides their actions. We should, however, probably eschew it as a 'category of analysis', preferring terms such as 'networks' for doing a more detached, generalising social analysis. ${ }^{14}$ Brubaker borrows the ideas of categories of practice versus analysis from Bourdieu, and is uncomfortable with the allencompassing fuzziness that the term social identity has acquired in recent years. He calls us to study actual patterns of social interaction, and regard any claims to identities associated with these with suspicion. For him, questions of identity are questions about the nature of social groups, or definable sets of social interactions, and personal identity tends to fall away as a concern.

In Identity as Ideology, Sinisa Malesevic also problematises the rising discourse of identity in the social sciences. He argues that the rigour with which the term 'identity' is formulated in logic and mathematics gives it a certain allure, but in practice in the social sciences, it is amorphous, covering many distinct social processes, without useful analytic precision and specificity. Moreover, he believes that it has come into currency at least partly because of a discursive

11 Jenkins, Social Identity, p. 23

12 Eriksen, T. H. 1993, Ethnicity and Nationalism: Anthropological perspectives, Pluto Press, London, p. 60.

13 Brubaker, R. 2004, Ethnicity without Groups, Harvard University Press, Cambridge, Mass.

14 Brubaker, R. and Cooper, F. 2000, 'Beyond "identity"', Theory and Society, vol. 29, no. 1, pp. 1-47, [Reprinted in ibid.]. 
vacuum in academic and popular discourse left by the decline of concepts such as 'race', 'national character' and 'social consciousness' as tools of social analysis. Malesevic opines:

Although 'identity' remains a highly popular concept, both in academic and everyday discourse it is conceptually, operationally and politically a seriously troubled idiom...the concept is so aloof and vague that it leads either to radically soft and loose uses where 'identity' stands for everything and anything, or it is articulated in a hard essentialist way so that through reified group membership the concept acquires features and attributes of individual human beings. ${ }^{15}$

For Malesevic also, identity is primarily a way of talking about group membership, and not a very good one at that.

In recent years another more extreme strain of ambivalence about the very idea of self-identity has arisen out of a theoretical milieu that combines elements of philosophy, psychoanalysis, and linguistic and literary theory, broadly labelled 'postmodern'. A prime example is the work of Judith Butler, heavily influenced by the work of Michel Foucault and Jacques Lacan. ${ }^{16}$ From the former she takes a strong scepticism about the existence of 'the subject' as anything other than a historical discursive formation; from the latter, the conviction that the very idea of self-identity is a kind of illusion, which arises at an early developmental stage as the child seeks to impose coherence on an incoherent state of being, by seeking stable markers of identity in the external world. These ideas feed into Butler's notion of 'performativity'. As I put it elsewhere, for Butler: 'Selves are fictions, inferred to make sense of the various actions and utterances - performancesthat proceed according to culturally defined scripts of behaviour, or "regulative discourses" in Foucauldian terms.' ${ }^{17}$ Thus, Butler views the very idea of stable, coherent self-identity as a kind of conceptual trap from which we should seek to escape through radical transgressive acts of performance that undermine regulative discourses.

Fighting a rearguard defence of the idea of the coherent self, in sociology at least, has been Derek Layder. Layder's approach has two main aspects. First, he conceives of persons as substantive entities with a basic need for powernot necessarily domination over others, but simply the capacity to achieve ends, to 'self-actualise'. Second, he argues that we understand the self by locating it conceptually and theoretically within abstracted layers: of situated

\footnotetext{
15 Malesevic, S. 2006, Identity and Ideology: Understanding ethnicity and nationalism, Palgrave Macmillan, Basingstoke, UK, p. 56.

16 Butler, J. 1990, Gender Trouble: Feminism and the subversion of identity, Routledge, New York; Butler, J. 2004, Undoing Gender, Routledge, New York.

17 Hearn, Theorizing Power, p. 199.
} 
interactions with other selves, of more enduring patterns of social relations constituted through social organisations and institutions, and finally at the most encompassing level of an environment of social resources, material and ideational, which shapes and can be drawn into various kinds of social interaction, and would include notions of collective identities. Contrary to the dominant trend, Layder happily distinguishes between identity as concrete and substantive self as social 'discourse', and makes the distinction a part of his approach to social analysis. ${ }^{18}$

The anthropologist Anthony P. Cohen also expresses deep reservations about the way modern social theory, in anthropology and beyond, has tended to theorise away the self, reducing individuality to the social roles prescribed by social structure. In this kind of unidirectional social analysis the impress of individual consciousness on society gets lost. As he puts it:

If we regard social groups as a collection of complex selves (complex, because any individual must be regarded as a cluster of selves or a multi-dimensional self) we are clearly acknowledging that they are more complicated and require more subtle and sensitive description and explanation than if we treat them simply as a combination of roles. Indeed, the aggregation of these complex entities into groups may itself be seen as more problematic than would otherwise be the case. Collective behaviour is then revealed as something of a triumph, rather than as being merely mechanical. ${ }^{19}$

I have great sympathy for the positions taken by Layder and Cohen. But the main thing I want to convey here is how embattled the idea of the self, and self-identity, has become, and to suggest this must have implications for a social-scientific approach to biography. Minimally it suggests that the same controversies must be replayed in the context of thinking through what a more sociologically sophisticated biography might entail. Perhaps more acutely, it suggests that taking biography seriously entails questioning 'constructivist' and 'performative' trends in the conception of identity in the humanities and social sciences.

\section{National Identity}

How does this connect to nationalism? In Nationalism Studies, definitions of 'national identity' are often formulated without any real concern for what

18 Layder, D. 2004, Emotion in Social Life: The lost heart of society, Sage, London; Layder, D. 2004, Social and Personal Identity: Understanding yourself, Sage, London; Layder, D. 2006, Understanding Social Theory, [Second edn], Sage, London. Cf. Wrong, D. H. 1996, The Problem of Order: What unites and divides society, Harvard University Press, Cambridge, Mass.

19 Cohen, A. P. 1994, Self Consciousness: An alternative anthropology of identity, Routledge, London, p. 7. 
'identity' means in general. Rather, a specific 'kind' of identity is defined, with the assumption that there are many such 'kinds', but these are largely the concerns of others. For instance, Ernest Gellner was adamant that in the modern world people normally require a national identity (a nationality) in the same way that they need two eyes and a nose. Everyone is expected to have one, and usually only one, because that is how the world has come to be organised: into large collectivities called nations. ${ }^{20}$ Anthony D. Smith proposes that the self is composed of multiple identities and roles', ${ }^{21}$ and that the major categories that underpin these are such things as: gender, territorial affinity and economic position. Smith pins down 'national identity' simply by pegging it to his concept of the nation: 'a named human population sharing an historic territory, common myths and memories, a mass, public culture, a common economy and common legal rights and duties for all members. ${ }^{22}$ National identity is simply the identity category attached to this kind of historical community.

Informed by rational-choice theory, Michael Hechter considers that many approaches, such as Smith's, too easily accept naturalised notions of the nation. He prefers to emphasise national identity as a category of group action that becomes salient under certain circumstances: 'Although the term "identity politics" is bruited about endlessly these days, it is far from clear why people come to primarily identify with one kind of group - say, a nation - rather than another - say a class. Whereas some culturally distinct groups develop national identities, others do not.'23

For Hechter, '[s]ocial identities are parasitic on group formation'. ${ }^{24}$ Thus again, though perhaps with a sharper focus on conducive conditions, national identities are social categories arising out of broad social conditions.

The sociologist David McCrone bemoans the lack of attention to national identity in the study of nationalism, objecting that it is too easily reduced to concepts of nation and nationalism, and not adequately dealt with in its own right. ${ }^{25}$ Influenced by the work of the anthropologists discussed above (Eriksen, Cohen and Jenkins, an erstwhile anthropologist who ended up in sociology), McCrone argues for an anti-essentialist view of identity as 'routes not roots'26 - that is, as an aspect of the active social construction of the future, rather than a binding category laid down in the past. To this end his work with various colleagues on national identity in Britain has stressed the way people situationally mobilise

20 Gellner, E. 1983, Nations and Nationalism, Cornell University Press, Ithica, NY, p. 6.

21 Smith, A. D. 1991, National Identity, Penguin, London, p. 4.

22 Ibid., p. 14.

23 Hechter, M. 2000, Containing Nationalism, Oxford University Press, Oxford, p. 97.

24 Ibid.

25 Bechhofer, F. and McCrone, D. 2010, 'Choosing national identity', Sociological Research Online, vol. 15,

no. 3, pp. 3, 11 .

26 McCrone, D. 1998, The Sociology of Nationalism, Routledge, London, p. 34. 
different markers of identity, ${ }^{27}$ deploy national identity in intimate and personal ways, ${ }^{28}$ and justify their choices of self-labelling in national terms. ${ }^{29}$ Thus, identity is the "'hinge" which connects structure and action'. ${ }^{30}$

\section{Discussion}

This grappling with identity, national and otherwise, evinces various reasons for holding the person's inner life at arm's length. On the one hand, when our questions are macro-sociological, concerned with history of the longue durée, it is understandable, and methodologically appropriate, that individuals largely fall from view. But within a narrower compass, where particular events or social groupings are the focus, it is not so clear why we should shy away from notions of the self. At one extreme there is the paradoxical Butler position: that the self is a powerful illusion that we must struggle to evade. But more generally I think we find variants of the view that the self is by definition non-observable and inaccessible to others. This has two implications. One is that it is not a proper object of social science; talking in terms of selves and what goes on in them can only lead to fruitless speculation. A variant on this, dating back to Durkheim, ${ }^{31}$ is that the self may be a proper object of psychological research, but precisely what differentiates sociology (and perhaps anthropology?) from psychology is that it sticks with the observably social. Another reason for reticence may simply be a kind of respect based, somewhat ironically, on the value of individualism. A certain respect for the individual obliges us to be circumspect in our attributions of feelings, motivations, and so on, to others. However we account for it, the main tendency is to treat identity either simply as large social categories-ideological, discursive or cultural constructs (take your pick) pegged to various forms of social organisation and structure (gender, nation, class, race, and so on) - or as the patterns of social action that imply, produce, reproduce and transform those categories. In short there are more structure-centred and more action-centred perspectives on social identity. But individuals with biographies tend to fall away in both cases, because action as much as structure tends to become an object in itself, the basis of an account rather than something that itself needs to be accounted for. The self remains a cipher from both perspectives.

\footnotetext{
27 Kiely, R., Bechhofer, F., Stewart, R. and McCrone, D. 2001, 'The markers and rules of Scottish national identity', Sociological Review, vol. 49, no. 1, pp. 33-55.

28 Bechhofer, F. and McCrone, D. 2008, 'Talking the talk: national identity in England and Scotland', in A. Park, J. Curtice, K. Thomson, M. Phillips and E. Clery (eds), British Social Attitudes: The 24th report, Sage, Aldershot, UK.

29 Bechhofer and McCrone, 'Choosing national identity'.

30 Ibid., pp. 1, 4.

31 Durkheim, E. 1966, The Rules of Sociological Method, Free Press, New York.
} 
Erik Erikson, Derek Layder and Anthony Cohen are the exceptions in the preceding account. They regard a social science without a conception of selves and personal identities as one of its elements as incomplete. This is not to deny that 'the self' is itself a culturally defined category. ${ }^{32}$ Modern 'Western' societies have tended to emphasise the idea of the individual as autonomous agent, while many others have tended to embed identity more firmly in kin and communal relations, or to conceive of the self as transcending the body. But diverse cultural constructions of selfhood do not rule out a common human experience of living our lives with our consciousness lodged in unique bodies, which must forge relations with other persons similarly situated.

I think that our talk about identity chronically treats it as a covering label for a relationship between two very distinct kinds of phenomena. On the one hand, there is the linguistic-symbolic categorisation of reality, which includes classifying human beings, including our selves, into different types or groups. On the other hand, as living creatures, we have consciousness and unique accumulations of experiences and memories, attached to historically particular and material bodies. For all its appearance of unity, and the efforts we put into binding selves to categories, the relationship between these two different kinds of things is unstable. These distinct processes do not merge into one unified phenomenon, whether regarded as structure or action. There is an ongoing relationship between these processes, but we understand it better by maintaining a clear conceptual separation. Far from treating selves and structures as the dubious shadows of a more real 'social interaction', or simply throwing our hands up and walking away in exasperation from the concept of identity, we need to recognise that we are talking about two different things, which nonetheless causally relate to one another.

I have confessed that I am not a biographer, and, in invoking notions of self and personal identity, I may be making certain assumptions about what it means to do biography. It is certainly possible to reconstruct a person's life with minimal attempt to reveal, or speculate about, their inner thoughts and motivations. ${ }^{33}$ But it seems to me this depends on the subject and the nature of the record available. A cache of highly personal letters would be difficult to interpret without making such attributions, and possibly difficult to ignore. A person known only through ancient historical accounts written down by their enemies (for example, Boudicca) poses real limits for any speculation about an inner life of the individual. But in many cases biography is based on various kinds of records of diverse social interactions in which the subjects were directly involved. So while evidence of inner states may be limited, because the

32 See, for example, Elliott, A. 2001, Concepts of the Self, Polity, Cambridge; Morris, B. 1994, Anthropology of the Self: The individual in cultural perspective, Pluto Press, London.

33 For example: Phillipson, N. 2010, Adam Smith: An enlightened life, Allen Lane, London. 
individual in question is the constant element in the study, it stands to reason that some notion of their personality, character, who they are as an individual person, and how these developed over their lives, will bear strongly on the coherence of a biographical analysis. If we are prepared to accept that the case study method can yield generalisable insights into social processes ${ }^{34}$ then surely this holds for biography. Thus, the merits of biography as a social-scientific venture rest not on some putative access to other minds, but on an appreciation of the way the particular can reveal aspects of the general. This requires at least a working hypothesis about the wholeness and coherence of the case, the person, the self and the biography in question.

\section{Three Metaphorical Approaches}

I introduce a measure of my own intellectual biography at this point. I do not presume that there is an audience interested in an overview of my work on (national) identity. Rather, doing so provides a way of putting a fuller proposal on the table about how to think about identity, in relation to biography and nationalism, against which to read the articles that follow.

I did not originally think of myself, post-PhD, as someone who works on 'identity'. I remember being somewhat bemused when, negotiating the subtitle of my first book with the editor, the suggestion kept coming back to me to work in 'national identity'. In the end I capitulated, aware that term had currency and general relevance to my study of home-rule politics in Scotland, and so the title Claiming Scotland: National identity and liberal culture was arrived at. ${ }^{35}$ But apart from some working definition of the concept in the introduction, there is little in the way of theoretical engagement with the concept in the book. If you had asked me about my main interests at the time, I would have said the 'social construction of history', 'liberal and communitarian debates', 'social movement' and then just 'nationalism' in the broadest sense. Coming from a rather Marxian graduate department in anthropology, I had picked up a general attitude of wariness towards the concept of identity, regarding it as often displacing more pertinent notions of class in social and political explanations. I would have said that the concept obviously had some utility, but was being rather oversold and overburdened. Frankly, I had not read anything on identity that had captured my imagination.

34 Flyvbjerg, B. 2001, Making Social Science Matter: Why social inquiry fails and how it can succeed again, Cambridge University Press, Cambridge, pp. 66-87.

35 Hearn, J. 2000, Claiming Scotland: National identity and liberal culture, University of Edinburgh Press, Edinburgh. 
Over the years, however, I have found myself returning to the question of identity's utility, as a concept for social analysis. It's obviously involved in how people forge links between their selves and their surrounding world, and how encompassing social categories are imposed on, received and resisted by individuals. And this process happens in socially patterned ways that make it consequential for processes such as social mobilisation, legitimation and solidarity. So, while the concept has often been asked to do too much, there appear to be some things it is well suited to doing. My cyclical engagements with the concept of identity have tended to deploy different metaphors in order to get some analytical leverage on the idea. In particular, the images of 'moods', 'embedding' and most recently 'ecology' have helped me articulate certain aspects of identity, so I will address these in turn, to compose a larger account.

In the article 'Narrative, agency, and mood: on the social construction of national history in Scotland', I was still making sense of ethnographic and other data collected for my $\mathrm{PhD} /$ first book, ${ }^{36}$ and primarily interested in how notions of historical narrative operated in the mobilisation of nationalism. As I put it then: 'How and why do people invest themselves in nations and nationalism? An important part of the answer lies in the ways that constructions of narrative and agency at the collective level articulate with experiences of narrative and agency at the personal level.' ${ }^{37}$

I proceeded by engaging Margaret Somers' work on narrative. ${ }^{38}$ Somers argued that narratives, such as national narratives, imposed a logical order on events through 'emplotment', and provided moral orientation to the world and its events through 'evaluative criteria' encoded in narratives. She related these practical and moral ordering effects of narrative to four different dimensions: ontological (that is, appropriations of narratives at the personal level); public (that is, narratives associated with specific institutions, organisations and networks, larger than the individual); metanarratives (that is, "master narratives' ${ }^{39}$ that encompass much or all of human history); and finally conceptual narrativesSomer's term for the kind of interpretative narratives formulated by academics and researchers, which often articulate with metanarratives.

To this I sought to add another aspect of narrative analysis, arguing two points. First, that narratives don't just frame social action to help make sense of it; they normally include key 'protagonists': large-scale collective agents such as nations, classes, ethnic groups or other categorical identities around which people

\footnotetext{
36 Ibid.

37 Hearn, 'Narrative, agency, and mood', p. 745.

38 Somers, M. 1992, 'Narrativity, narrative identity, and social action — rethinking English working-class formation', Social Science History, vol. 16, no. 4, p. 591; Somers, M. 1994, 'The narrative constitution of identity: a relational and network approach', Theory and Society, vol. 23, pp. 605-49.

39 As in Lyotard, J.-F. 1984, The Postmodern Condition: A report on knowledge, University of Minnesota Press, Minneapolis.
} 
mobilise. Thus, when people invest themselves in a narrative account, they are identifying their own person with that protagonist, fusing their individual agency with that larger agency. This basic process of identification through narrative, while often taken for granted, doesn't receive the scrutiny it deserves. Moreover, I suspect that the ease with which one can imagine links between the agentic self and some larger collectivity is consequential. Like it or not, the claims of 'nations', as communities with a symbolised collective identity, claims to shared values and rights to self-determination within a specific territory ${ }^{40}$ are perhaps more susceptible to making this linkage than more diffuse and fractious collectivities such as 'the working class' or 'women'. Their very boundedness and historicalness make them amenable to personification, and thus also to being objects in which personhood is invested.

Second, I argued that narratives don't just encode and make sense of past actions; they are often posed as predictive of the future, and encode agentic situations and dispositions to act. National narratives are often by definition incomplete, locating the person who identifies with it midway in an open-ended narrative. Thus, they offer not just an account, but also a kind of dramatic setting in which the agents' (persons and nations) capacity for and conditions of action are framed. They define not just a series of events, but a disposition for actions. I called this aspect of narratives their 'mood', by which I meant both that they encode certain feelings about agency and that, like grammatical verb forms, they encode characteristic notions about action. I suggested that for analytic purposes we can posit three paradigmatic types of mood:

Those in which the protagonist is portrayed as moving/acting 'with the flow' of an encompassing historical narrative. For example, the general ideological compatibility of middle-class Scottish national aspirations with the British imperial project in the middle of the nineteenth century. ${ }^{41}$

Those in which the protagonist is portrayed as moving/acting 'against the flow' of an encompassing historical narrative - for example, the development of quasi-Marxist nationalist narratives that cast Scotland as a colony of England, struggling to break its bonds, which came into currency on the Scottish nationalist left from the 1960s through to the 1980s. ${ }^{42}$

Those in which the relationship between protagonist and its history are portrayed in much more open terms of competing 'cross-currents' with a range of possibilities. I argued that in Scotland in the 1990s the nationalist historical

40 Cf. Hearn, J. 2006, Rethinking Nationalism: A critical introduction, Palgrave Macmillan, Basingstoke, UK, pp. 11-13.

41 See Morton, G. 1999, Unionist-Nationalism: Governing urban Scotland, 1830-1860, Tuckwell, East Linton, UK.

42 See Hechter, M. 1975, Internal Colonialism: The Celtic fringe in British national development, 1536-1966, University of California Press, Berkeley; and Nairn, T. 1977, The Break-Up of Britain, Verso, London. 
discourse was shifting in this direction, as the possibility of devolution was becoming a reality, and a less determinist and more flexible narrative was needed to make sense of the range of political possibilities. ${ }^{43}$

As indicated, I illustrated my theoretical argument by relating it to how Scottish national history and character have been represented, both as formal history and as more general talk about the nation. I noted at the time that perhaps the best way of developing the argument further would be 'through an in depth treatment of biographical material' ${ }^{44}$ I still have not tried to systematically pursue a more biographical study to test this conceptual framework, but believe it could be illuminating.

Meanwhile in 2001-02 I conducted a year of ethnographic research into the everyday production and enactment of national identity in organisational/ institutional settings. Specifically, I worked at the Bank of Scotland during its first year of merger with Halifax (based in the north of England) to form HBOS (2001-02). Moving between the two banks, though primarily based at the Bank of Scotland, I investigated how staff were using notions of national identity and national difference, especially between Scottish and English, to make sense of the stresses and strains of the merger, which were being experienced as an encounter between two 'national' banks.

It was during that research, because of its remit, that I began to think more systematically about identity, national and otherwise. The data I was collecting, through observation, participant observation, questionnaires and interviews, increased my dissatisfaction with an approach to identity that talks as though identities are multiple roles that we step into and out of according to the situation, viewing identity as lying primarily in its performance in social interaction. My overriding sense was that I was trying to understand people who, as much as they didn't want to be 'pigeonholed', experienced their identities as going well below the surface of daily interaction, of being fateful for their lives in certain ways. At the same time there was a clear, conscious sense of the hiatus between identity in this personal sense, and the various discursive categories-Scottish, English, and so on - that people regularly had to negotiate.

A few years later I tried to address this sense of a theoretical inadequacy in regard to identity through that ethnographic material. ${ }^{45}$ I took as my starting point two attempts to get at national identity, not as high-flown ideology, but as everyday and intimate. On the one hand, there was Michael Billig's influential notion of 'banal nationalism', as the deeply ingrained habits and discourses that

43 See Paterson, L. 1994, The Autonomy of Modern Scotland, Edinburgh University Press, Edinburgh.

44 Hearn, 'Narrative, agency, and mood', p. 758.

45 Hearn, 'National identity'. 
reproduce the social category of national identity in implicit, unnoticed ways. ${ }^{46}$ I argued that while this idea had sometimes been taken as providing pointers to how national identity 'beds down' into persons, in fact Billig's concern was with nationalism as ideology and discursive category, with little interest in identity at the personal level. There was a tendency to confuse a focus on the micro and implicit with focus on the personal, which isn't necessarily the same thing.

On the other hand, I looked at Anthony P. Cohen's formulation of 'personal nationalism' ${ }^{47}$ In keeping with his general concern discussed above about the neglect of 'selves' in social science, he had been struggling to understand nationalism as more than just a discursive category draped over intractable selves. In sum, he argued that where national identity is available as a stable and widely recognised social category (as in Scotland), far from erasing or obscuring individuality, it provides a medium (among others) for articulating personal identities. Cohen emphasises the flexible and open nature of national identity, treating it as a condition for the realisation of individuality, whether through investment in or resistance to that identity (or more likely a complex combination of both).

Thus, I argued that Billig was more concerned with the social category (ideology, discourse) of national identity and relatively unconcerned with the personal, while Cohen was more concerned with personal inhabitation of national identity and fairly unconcerned with the social category itself. But what is needed is precisely an approach that acknowledges this distinction, and treats the relationship between these very different phenomena as its core problematic. In the article in question, I did this through a metaphor of 'embeddedness', drawing on the ideas of Derek Layder mentioned above. I argued that not only are there two very distinct meanings of 'identity', but also these are mediated by intervening structures. As already indicated, Layder proposes an analytic model of layers, with the self at the centre, successively embedded within layers of more immediate conventions of social interaction, and progressively more 'distant' and encompassing layers of cultural and institutional resources that frame and steer social interaction. I sought to flesh out this perspective by treating the bank(s) as an organisational work environment that had an important mediating effect between national identities as social categories, and as aspects of personhood, for the people I was studying. For many of them, the significance of the categories 'Scottish' and 'English' was being filtered, by force of circumstances, through the experience of the encounter between the two merging banking organisations in which they were embedded. For

\footnotetext{
46 Billig, M. 1996, Banal Nationalism, Sage, London.

47 Cohen, A. P. 1996, 'Personal nationalism: a Scottish view of some rites, rights, and wrongs', American Ethnologist, vol. 23, no. 4, pp. 802-15; Cohen, A. P. 2000, 'Peripheral vision: nationalism, national identity and the objective correlative in Scotland', in A. P. Cohen (ed.), Signifying Identities: Anthropological perspectives on boundaries and contested values, Routledge, London.
} 
many, being Scottish became particularly freighted with a reputation for being old-fashioned, conservative, slow moving, diffident (banking as was), rather than thrusting, dynamic, self-confident, on the move - terms associated more with Halifax and 'Englishness' more generally. This puts it schematically, and obviously matters were more complex than this. And my informants were perfectly capable of questioning this pattern of ideas and associations, while nonetheless being caught up in it.

My key point was that the relationship between categorical and personal identities will always be mediated by intervening forms of social organisation. These refract the category into individual experience, and project those experiences, however weakly, back out into the category. This study provided a very particular case of how this was happening in regard to a 'national' bank. The mediations in question will be very different in other contexts, such as militaries, political parties, sports teams, universities, public services, major cities, and so on, ad infinitum. Although some are more explicitly associated with 'nationality' than others, all will have the potential to play a role in mediating national identity, according to specific circumstances. And for any individual there will be multiple forms of social organisation in their lives doing this mediating. Most obviously, on a small scale and in very immediate ways, families mediate the category of the nation for the individual, some heightening it, some playing it down, some, such as where parents are of different nationalities, problematising it in their very constitution.

A chapter in my latest book on theorising power attempts to bring together my thinking on identity in general, particularly in the context of power. ${ }^{48}$ There I use the metaphor of 'ecology' to express what I have just been arguing. In other words, I suggest that we should think of identity as emerging out of a pattern of interactions (an ecology) between these three elements: 1) selves with unique biographies and identities, 2) social identity categories through which we cognitively organise and make sense of the social world, and 3) multiple mediating forms of social organisation. In my view, much social theory about identity errs when it tries to reduce identity to either (1) or (2), or to some very abstract notion of interaction between them, which becomes more 'real' than either of them.

In that book, and through this ecological metaphor, I emphasise the role of power. It is not just that selves, social categories and forms of organisation together outline a balance of forces involved in a relatively stable but dynamic and evolving set of relations. More crucially, each of these three defines a level at which problems of power crystallise. In regard to the 'self', figures such as Erikson and Layder recognise - and I agree - that the power to act, to exhibit 
some degree of agency and self-determination, is a defining feature of the self. Selves need power, not necessarily in the sense of the capacity to dominate others, but more fundamentally in the sense of the capacity to act and have an effect on their lives and circumstances. Good relations between persons are characterised not by the absence of power, but by its negotiation, its balance and distribution. Indeed, caring for others is a demonstration of power well executed. Pathologies in personal psychology and interpersonal dynamics arise precisely when power is not effectively negotiated and regulated. In many ways the power of the individual agent provides our commonsense paradigm of what power is: the capacity to have intended effects. ${ }^{49}$ We often understand more organisationally and institutionally complex forms of power (for example, of states, corporations, and so on) as ramped-up versions of nonetheless coherent individual actors realising intentions.

Social taxonomies are also bound up with power. In all their forms, they come into existence as means for apprehending and controlling the world around us. They have basic practical power implications. And of course, systems of categorisation can be and are used to gain power by some people over others; they imply not just power, but domination. Social identity categories encode notions of power relations, and the legitimation of those relations. ${ }^{50}$ Moreover, the categories are subject to revision, and are under construction, and that process becomes an arena of power contests over who can define the categories, to what ends. Individuals, with their self-identities, are confronted with fundamental existential questions about what categories will be imposed on them, which ones they have some choice in and how to calculate the advantages and disadvantages. But much of the time simply 'opting out' isn't an option.

Organisation is central to the constitution and disposition of power. As Gaetano Mosca put it: 'the dominion of an organized minority, obeying a single impulse, over the unorganized majority is inevitable. ${ }^{.51}$ Our lives are organised in an encompassing social structural sense. Where we fit into a landscape of power positions defined by class, gender, religion, ethnicity, urban-rural relations and so on, determines our fates and possibilities to some degree, but also in the more circumscribed sense of formal organisations - which is more what Mosca was talking about. Our power in life and over our own fates depends greatly on what organisations we are a part of, and our positions in them. These are the main means by which we magnify our individual wills into larger collectivities and achieve efficacy on a larger scale. Formal organisations follow the paradigm

49 Cf. Russell, B. 2004, Power: A new social analysis, Palgrave Macmillan, Basingstoke, UK, and New York.

50 Jenkins, Social Identity, p. 79-93.

51 Mosca, G. 1939, The Ruling Class, Elementi Di Scienza Politica, A. Livingston (ed.), H. D. Kahn (trans.), McGraw-Hill, New York; cf. Mann, M. 1986, The Sources of Social Power. Volume I: A history of power from the beginning to A. D. 1760, Cambridge University Press, Cambridge; and Galbraith, J. K. 1983, The Anatomy of Power, Houghton Mifflin, Boston. 
of individual agency because that's what they're there for in many respects. And this point echoes the one made earlier about narratives and the fusion of the protagonist roles, between individual selves and larger collectivities such as nations. How we invest our selves in these larger categories, and the various forms of organisations that mediate between us and those categories, reflects how effective the linkages are at constituting and challenging power relations. The personal, the categorical and the organisational are all political, and particularly so in combination.

\section{Conclusions: Biography and power}

I've talked about the problems of conceptualising identity, national and otherwise, in my own work and the work of others. I've tried to treat 'identity' not as a proxy for biography, but as a conceptual framework for thinking about the biographical study of nationalism. It seems to me that biography provides a powerful means of examining how categorical national identities are attached to personal identities, and the complexities of this process. Each biography is 'a case' of that process, which will reveal specific aspects of how it happens. Despite their uniqueness, case studies provide insights into complex processes. The framework of an 'ecology' of self-identity, social identities and mediating organisations is meant to provide clues to the comparability between cases. So this is not a matter of privileging the individual as a unit of analysis, but of recognising individuals, with their biographies and self-identities, as a distinctive element in a wider social analysis. This is not a matter of essentialising selves, but rather of appreciating how they are capable of development and change. One of the most intriguing issues in this area is that of people who undergo radical transformations of identity, fundamentally changing how they understand themselves and their relations to social identity categories (for example, religious or political conversion).

Finally I also believe that power provides a key to how and why persons attach their biographies to categorical identities, such as nationalism. I think the study of power and identity has tended to be biased in its attention towards identity as social category. On the positive side there is the recognition that getting people to participate in certain collective identities is a crucial part of political mobilisation for change. On the darker side is the recognition that such acts of identity categorisation can involve schemes of domination between groups, social control by states and 'regulative discourses' ${ }^{52}$ But as social scientists we have been slower to recognise that the search for power is not simply a matter of domination, but also an existential aspect of being human. As healthy 
individuals, we need to have some power over our lives, and this search is inscribed in our identities and laid down in our biographies. The various ways people connect and disconnect their personal identities and their collective identities reveal struggles for and against power. The study of biography and nationalism provides a rich vein of material about this fundamental process, one that deserves continued and closer scrutiny. 